\title{
The Implication of Metabolic Performance of Mytilus Edulis, Mytilus Trossulus, and Hybrids for Mussel Aquaculture in Eastern Canadian Waters
}

\author{
Rejean Tremblay ${ }^{1 *}$, Thomas Landry ${ }^{2}$ \\ ${ }^{1}$ Institute of Ocean Sciences, University of Quebec at Rimouski, 310 allée des Ursulines, Rimouski, Quebec, Canada \\ ${ }^{2}$ Department of Fisheries and Oceans, Aquaculture and Coastal Ecosystem Section, Gulf Fisheries Centre, Moncton, NB, Canada
}

*Corresponding author: Réjean Tremblay, Institute of Ocean Sciences, University of Quebec at Rimouski, 310 allée des Ursulines, Rimouski, Quebec G5L 3A1,Canada, Tel: +1-418-723-1986; Fax: 1-418-724-1842; E-mail: Rejean_Tremblay@uqar.ca

\begin{abstract}
Mussel aquaculture is a significant industry in Eastern Canada where the blue mussel, Mytilus edulis and the bay mussel, M. trossulus co-occur. Generally mussel farmers associate $M$. trossulus with significant loss of productivity because of low meat yields and fragile shell. Previous studies on homogenous M. edulis populations have demonstrated that individuals showing the greatest performance are characterized by a lower standard metabolism related to higher multi-locus heterozygosity (MLH) level based on specific allozyme markers. These mussels rely less on their energy reserves to maintain vital functions and had more energy available to support physiological responses to stress at high temperatures. Mussels with high MLH levels also had lower mortality and higher growth rate. In this study, the metabolism performance of each species and their hybrids were estimated along with their respective MLH. For each species (M. edulis and M. trossulus) and hybrids, we observed that individuals with lower standard metabolic rate having higher MLH. Furthermore, M. edulis was characterized by higher MLH, lower standard metabolism and higher growth (estimated in length and mass) compared to $M$. trossulus and hybrids. We provide the economic and ecological implications of these findings for mussel aquaculture in Eastern Canada.
\end{abstract}

Received date: December 9, 2015

Accepted date: January 4, 2016

Published date: January 7, 2016

Citation: Tremblay, R., et al. The Implication of Metabolic Performance of Mytilus Edulis, Mytilus Trossulus, and Hybrids for Mussel Aquaculture in Eastern Canadian Waters. (2016) J Marine Biol Aquacult 2(1): 1-7.

DOI: $10.15436 / 2381-0750.16 .009$

\section{Introduction}

The bivalve aquaculture industry has become an important socio-economic component of many coastal communities throughout the world and marine molluscs presently account for $60 \%$ of global marine aquaculture production ${ }^{[1]}$. Largely cultivated on the east of Canada (over 20,000 tons per year), the mussel industry represents an annual market of around $\$ 30$ million ${ }^{[2]}$. Wild seed collection remains a critical activity for the bivalve aquaculture industry. In Eastern Canada, the availability of mussel seeds is not a concern from a quantitative standpoint, however, it has potential limitations from a qualitative stand ${ }^{[3]}$. Populations of the blue mussel, Mytilus edulis and the bay mussel, M. trossulus coexist in the Gulf of St. Lawrence, Scotian Shelf and Gulf of Maine. Along the Atlantic coast of North America, M. edulis extends from Newfoundland and Labrador (Canada) to North Carolina (USA), while M. trossulus is restricted to sub-polar areas with a southern distribution limit in the Gulf of Maine ${ }^{[4-7]}$. In these areas, the frequency of hybridization between these two species of the Mytilus complex is low and generally $<10 \%{ }^{[4,8-10]}$, suggesting that the process of hybridization seem limited in this region ${ }^{[11]}$. The mussel aquaculture industry in Atlantic Canada is significantly influenced by genotype-dependent growth variation in areas where seeds collection of both M. trossulus and M. edulis occurs ${ }^{[12]}$. Thus, the presence of these two species could have a significant impact on the productivity of a mussel farm ${ }^{[13,14]}$. M. edulis is generally considered to outperform M. trossulus, by their higher growth rate ${ }^{[12,15]}$ and their thicker and stronger shell ${ }^{[16]}$ less susceptible to shell breakage during primary processing ${ }^{[13,17]}$. 
Previous studies conducted on $M$. edulis showed that the higher susceptibility of mussels stocks to stress was related to higher maintenance requirements and low Multiple-Locus Heterozygosity (MLH) ${ }^{[18,19]}$. Important modifications of the metabolism are required to maintain internal environment as constant as possible under stressful conditions, resulting in a higher protein turnover caused by the synthesis of proteins such as chaperone proteins and the reparation/denaturation of damaged proteins ${ }^{[20]}$. More heterozygous individuals had a higher protein synthesis efficiency and a higher scope for growth compared to more homozygous individuals ${ }^{[21]}$. Furthermore, Myrand et al. ${ }^{[22]}$ showed that the total wet weight of $M$. edulis with high MLH were twice that of the mussels with low MLH, after one year of suspension culture. As the use of genetic characteristics, like MLH has been shown to be a reliable indicator of physiological fitness in M. edulis ${ }^{[23]}$, there is some interest in assessing this indicator/tool for the two species, within similar environment.

In this study, we tested the hypothesis that fitness-related mussel traits in aquaculture sites could be easily identified by physiologically based indicators. The objectives of this study is to validate the seed quality in terms of 1) growth (in mass and length), 2) standard metabolism linked to MLH and then 3) link these performance measurements with species composition.

\section{Materials and Methods}

\section{Species Composition}

Wild intertidal mussels were collected in May 2007 from 3 bays in Nova Scotia, Canada (Allains 44'43.001N, 65'31.599W; LaHavre 44'17.461N, 64'22.3W and St. Anne's $46^{\prime} 11.441 \mathrm{~N}, 59^{\prime} 57.431 \mathrm{~W}$ ) at two sites by bay. At each site, 105 individual mussels were randomly selected and the first 35 mussels collected in each length category $(5-15,>15-25$ and $>25-50$ $\mathrm{mm}$ ) had their length recorded and a sample of $200 \mathrm{mg}$ of tissues was preserved at $-80^{\circ} \mathrm{C}$ for species identification by molecular markers. Species identification has been estimated on 630 individuals.

\section{Growth Experiment}

This experiment was conducted with mussels from Country Harbour (Nova Scotia, Canada) where the presence of the two species of mussels had been confirmed in preliminary analysis. On July10, 2007, the period with higher monthly growth rate ${ }^{[24]}$, mussels $(34.3 \pm 0.4 \mathrm{~mm})$ were collected and put into condo cage, described in LeBlanc et $\mathrm{a}^{\left[{ }^{[3]}\right.}$ and attached to three different mussel long lines in Country Harbour bay $\left(45^{\prime} 10.370 \mathrm{~N}, 61^{\prime} 42.241 \mathrm{~W} ; 45^{\prime} 11.105 \mathrm{~N}, 61^{\prime} 42.819 \mathrm{~W}\right.$ and $\left.45^{\prime} 11.564 \mathrm{~N}, 61^{\prime} 43.275 \mathrm{~W}\right)$. On each long lines, two condo cages (with 32 individual compartments in each cage) were filled with individual mussels at a depth of 2-3 m. After 8 weeks, the mortality was estimated on the 192 mussels before their transfer in the wet laboratory for standard metabolism quantification and genetic characterization. During the field trials, water temperature varied from 17 to $21^{\circ} \mathrm{C}$. Mussel's farms in Canada use sleeves suspended on long-line culture systems, but this method cannot be used to follow mortality, like cage suspended on longlines $^{[3,24]}$.

\section{Standard Metabolic Rate Measurements}

At arrival in wet laboratory, mussels were feed with a
1:1 mixture of Isochrysis galbana and Chaetoceros gracilis at a concentration of $10^{4}$ cells ml-1 ${ }^{-1}$ Mussels were maintained at 15.7 $\pm 0.3^{\circ} \mathrm{C}$ and salinity of $27.2 \pm 0.2 \mathrm{psu}$. After three weeks of acclimation in laboratory condition, mussels were starved during 7 days before oxygen consumption measures were made to estimate standard metabolism ${ }^{[25]}$. Individual mussels were held in a respirometry chamber of $500 \mathrm{ml}$ (one mussel by chamber) filled with oxygen-saturated seawater that had been filtered $(0.45 \mu \mathrm{m})$ and treated with UV light. Seven mussels and one control (empty shell) were measured simultaneously (Figure 1). Each mussel was acclimated to the respirometry chamber for $1 \mathrm{~h}$ at the temperature treatment. Partial oxygen pressure kept well-mixed using a magnetic stirrer. Oxygen consumption was determined by sealing the metabolic chambers and measuring the decrease in dissolved oxygen with a YSI (5331) polarographic electrode coupled to a YSI micro-oxymeter (Yellow Springs, OH, USA). The output signal was monitored continuously on a flat bed chart recorder (Cole-Parmer, Montréal, Canada) until there was a 20\% decrease in oxygen saturation. Following metabolism measurements, shell length was measured and a sample of $200 \mathrm{mg}$ of tissues was preserved at $-80^{\circ} \mathrm{C}$ for species identification by molecular markers while another sample of $200 \mathrm{mg}$ was preserved for allozyme analyses. All others tissues were collected to determine the dry mass, after desiccation at $70^{\circ} \mathrm{C}$ for $72 \mathrm{~h}$ and oxygen consumption was standardized for a $1 \mathrm{~g}$ mussel using the allometric relationship: Standardized $\mathrm{VO}_{2}(\mathrm{ml} /$ individual $/ \mathrm{h})=(1 \mathrm{~g} /$ dry mass ${ }^{0.65}$ measured $\mathrm{VO}_{2}{ }^{[26]}$. Condition index of each mussel were determined by dry meat mass on dry shell mass X 100. We assume that condition index was positively related to the global physiological status of the mussels.

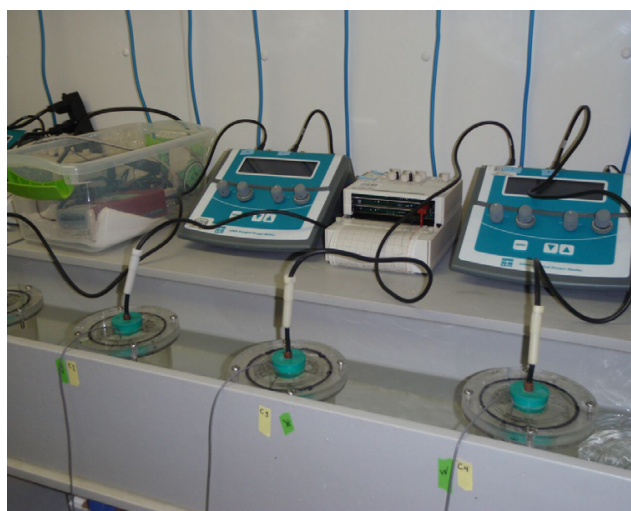

Figure 1: Experimental setup for the Standard metabolic rate measurements

\section{Genetic Characterisation}

The molecular markers ITSR2 and Me1516 loci were used for species identification (Table 1). For ITSR2, any fragments between 358-429 bp were considered M. edulis specific and fragments between 182 and 198 were considered M. trossulus specific. For Me1516, any fragments between 172 and 177 bp were considered M. edulis specific and fragments between 161 and $167 \mathrm{bp}$ were considered M. trossulus specific. Individuals were categorized as M. edulis or M. trossulus if they showed only bands specific to that species at both loci. If the individual showed fragments specific to each species at one or both loci, they were categorized as a hybrid. DNA was extracted from fresh tissue for each sample using the DN easy 96 kit (Qiagen, Mississauga ON). The optional RNase treatment step 
was not performed and the DNA was eluted in $100 \mu \mathrm{l}$ AE (Qiagen, Mississauga ON). For mussels $<10 \mathrm{~mm}$ the whole mussel was used for the extraction and the shell was crushed with a pipet tip to allow penetration of the solutions. Mussels between 10 and $20 \mathrm{~mm}$ were opened and the whole tissue removed. For mussels larger than $20 \mathrm{~mm}$, only $25 \mathrm{mg}$ of tissue was used for the extraction. The DNA was quantified using the PicoGreen assay (Invitrogen, Burlington $\mathrm{ON}$ ) and the fluorescence measured using a FLUO Star OPTIMA (BMG Labtech, Cary NC). Prior to PCR the samples were normalized to $10 \mathrm{ng} \mu \mathrm{l}^{-1}$. All PCR (Polymerase chain reactions) were performed in $10 \mu \mathrm{l}$ reactions containing 25 ng DNA, 1X PCR buffer (Qiagen, Mississauga $\mathrm{ON}$ ), $1.5 \mathrm{mM} \mathrm{MgCl}$ (Qiagen, Mississauga ON), dNTPs as 0.6 $\mathrm{mM}$ dUTP and $0.2 \mathrm{mM}$ each dATP, dCTP and dGTP, $0.125 \mu \mathrm{M}$ each primer (Applied Biosystems, Carlsbad CA; see Table 1) and 0.5 U Taq (Qiagen, Mississauga ON). PCR cycles consisted of an initial denaturation step of $94^{\circ} \mathrm{C}$ for $2 \mathrm{~min}, \mathrm{n}$ number of cycles (see Table 1) of $94^{\circ} \mathrm{C}$ for $30 \mathrm{sec}, 52^{\circ} \mathrm{C}$ for $30 \mathrm{sec}$ and $72^{\circ} \mathrm{C}$ for $45 \mathrm{sec}$; a final extension of $72^{\circ} \mathrm{C}$ for $10 \mathrm{~min}$. The ITSR 2 is an RFLP locus, and the entire PCR reaction was used in the $15 \mu \mathrm{L}$ (final volume) restriction digest. The HhaI digest contained 1X Buffer 4 (New England Biolabs, Pickering ON), 1X BSA (New England Biolabs, Pickering ON) and 3U HhaI (New England Biolabs, Pickering ON). The digestion reactions were incubated at $37^{\circ} \mathrm{C}$ for $6 \mathrm{~h}$ followed by a heat inactivation step of $65^{\circ} \mathrm{C}$ for $20 \mathrm{~min}$. All PCR reactions and restriction digests were carried out in an Eppendorf ep master cycler gradient thermal cycler (Eppendorf, Mississauga, ON). For each sample, $2 \mu 1$ of each of the PCR reactions for the two loci (ITSR2 digested with HhaI and Me1516) were combined and purified using a Multiscreen PCR $\mu 96$ plate (Millipore, Billerica MA) following the manufacturer's instructions with a $20 \mu$ l elution. The purified products $(0.5 \mu \mathrm{l})$ were combined with $9 \mu \mathrm{l}$ HiDiformamide (Applied Biosystems, Carlsbad CA) and $0.5 \mu$ l GeneScan 600 LIZ (Applied Biosystems, Carlsbad CA) size standard and run on an AB3130xl (Applied Biosystems) capillary electrophoresis system using a $36 \mathrm{~cm}$ array and POP7 polymer. The resultant electropherograms were analyzed using GenMapper 4.0 (Applied Biosystems, Carlsbad CA).

Table 1: Primer sequences and PCR conditions for loci ITSR2 and Me1516. Primer sequences are written 5' to 3'; the fluophore is indicated with the primer that was labelled in brackets; $n$ is the number of cycles in the PCR used and the reference lists for each primer, where there are multiple references, the primers referred are in brackets.

\begin{tabular}{|c|c|c|c|c|}
\hline $\begin{array}{l}\text { Lo- } \\
\text { cus }\end{array}$ & Primers & $\begin{array}{l}\text { Fluo- } \\
\text { phore }\end{array}$ & $\begin{array}{c}\text { Cycles } \\
\text { (n) }\end{array}$ & Reference \\
\hline $\begin{array}{l}\text { ITS } \\
\text { R2 }\end{array}$ & $\begin{array}{c}\text { ITSF (GTTCCGTAGGT- } \\
\text { GAACCTG) } \\
\text { ITSR2 (TGATCCACCG- } \\
\text { CCTAGAGTA) }\end{array}$ & $\begin{array}{l}\text { 6-FAM } \\
\text { (ITSF) }\end{array}$ & 32 & $\begin{array}{l}\text { (Heath, 1995) } \\
\text { (ITSF) (L.Ham- } \\
\text { iltonpers.comm) } \\
\text { (ITSR2) }\end{array}$ \\
\hline $\begin{array}{c}\mathrm{Me} \\
1516\end{array}$ & $\begin{array}{c}\text { Me15 (CCAGTATA- } \\
\text { CAAACCTGTGAAGAC) } \\
\text { Me16 (TGTTGTCTTA- } \\
\text { ATAGGTTTGTAAGA) }\end{array}$ & $\begin{array}{c}\text { VIC } \\
(\mathrm{Me} 15)\end{array}$ & 30 & (Inoue, 1995) \\
\hline
\end{tabular}

The allozymes chosen for this study were polymorphic enzymes implicated in metabolic functions and already documented to be related to fitness parameters in M. edulis ${ }^{[22]}$ (Myrand et al., 2002). Allozyme analyses were carried out on groups of $M$. edulis, $M$. trossulus or hybrid after individual species identification following the methods described below. Allozyme analysis was carried out on horizontal acetate plate, as described in Tremblay et $\mathrm{al}^{[27]}$. The polymorphic enzymes studied were mannose phosphate isomerase $\left(M P I^{*}\right.$, EC 5.3.1.8), phosphoglucomutase $\left(P G M^{*}\right.$, EC 2.7.5.1), octopine dehydrogenase $\left(O D H^{*}\right.$, EC 1.5.1.11), glucose phosphate isomerase (GPI*, EC 5.3.1.9) and leucine aminopeptidase $\left(L A P^{*}, \mathrm{EC} 3.4 .11\right)$. A standard of all known alleles was prepared by mixing homogenates of individuals of different genotypes was used on each gel for comparison to aid in exact allele identification.

\section{Statistical Analyses}

Statistical tests were performed with SAS 9.2 (SAS Institute Inc., Cary, NC, USA). For each model, residuals were screened for normality using the normal probability plot and then tested using the Shapiro-Wilk's statistic. Homogeneity of variances was graphically assessed using residual plots and further tested using Bartlett's test. When differences were detected, a posteriori comparisons was performed on the LSMEANS and a sequential Bonferroni correction was applied to keep the type I error at the overall level of $0.05^{[28]}$. Composition of mussel species for each site was compared by a two-way ANOVA model with stocks (2) and size (3) as factors after arcsine square-root transformation to homogenize variances. Survival were analysed by one-way ANOVA with cages as factors. MLH, standard metabolism, shell growth and dry tissues mass were analysed by one-way ANOVA with species as factors. When necessary, data were $\log (\mathrm{x}+1)$ transformed to achieve normality of residual and homogeneity of variance. Simple Pearson correlations were used to evaluate the relation between MLH with basal metabolism, growth of shell, dry tissue mass and condition index for $M$. edulis, M. trossulus and hybrids. The number of heterozygous loci per mussel (zero to five) was used to characterize individual multi-locus heterozygosities (MLH). Frequency distributions of the number of heterozygous loci between different mussel stocks were compared with a series of one-tailed Wilcoxon tests after sequential Bonferroni corrections.

\section{Results}

\section{Genetic Characteristics}

Mussels from Alain and Le Havre Bays in Nova Scotia had high proportions of M. trossulus and hybrids (from 25 to $89 \%$ ) while those from St-Anne were characterized by very low $(<3 \%)$ presence of $M$. trossulus and only in the smaller mussel (15-25 mm; Figure 2). In Alain and Le Havre sites, the presence of $M$. trossulus decrease significantly with the size of the mussels with $M$. edulis dominating in mussels between 25 to $50 \mathrm{~mm}$. In Le Havre Bay, the proportion of M. edulis was lower overall, reaching a high of $48 \%$ in larger $25-50 \mathrm{~mm}$ mussels. The proportion of hybrids in Alain Bay was lower (15\%) comparatively to Le Havre Bay (30\%) without significant influence from mussel size. In St. Anne Bay, the proportion of hybrids was similar to $M$. trossulus (around 3\%) and only observed in the size class 15-25 $\mathrm{mm}$. The hybrids level were generally low but the use of higher number of molecular markers could increase the resolution of species identification and the level of hybrid observed. 


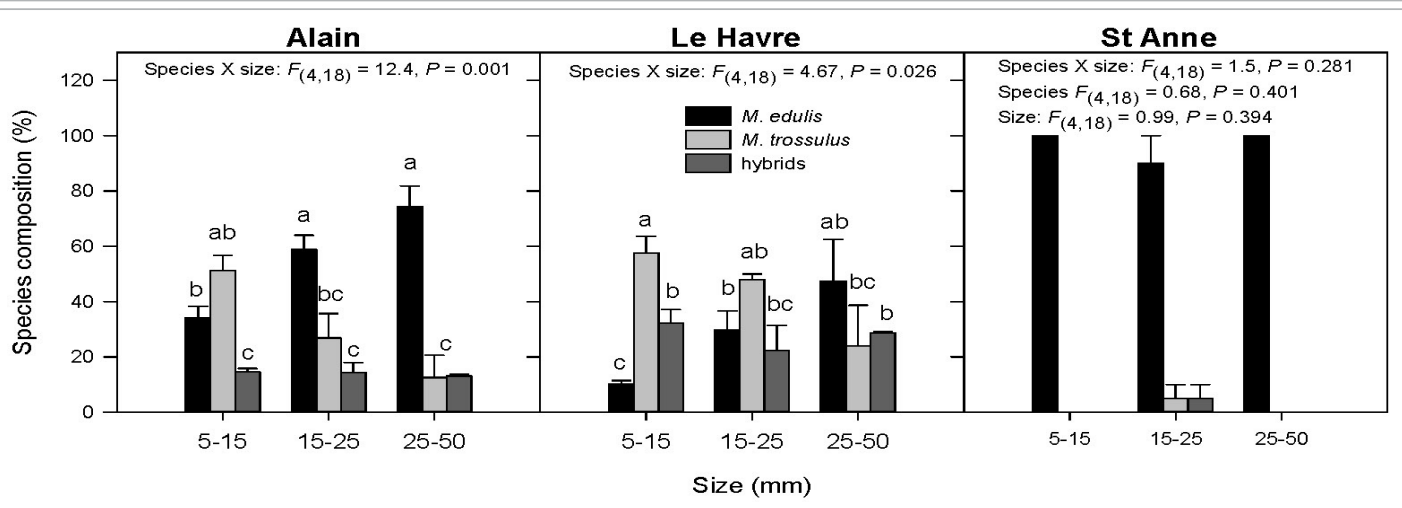

Figure 2: Species composition in each site for each size class. $n=70$ by size class for each site.

\section{Growth Experiment}

After 8 weeks in condo cages, mortalities were less than $10 \%$ and similar in all cages $\left(\mathrm{F}_{(2,3)}=0.167, \mathrm{P}=0.854\right)$. Mussels from County Harbour were composed of $55 \%$ M. edulis, $24 \%$ hybrids and $21 \%$ M. trossulus. M. edulis and hybrids had significantly higher multiple locus heterozygosity (MLH; $1.23 \pm 0.09$ and $0.98 \pm 0.14$, respectively) measured on allozyme loci $>1$ (for a maximum of 5), in comparison with M. trossulus $(0.67 \pm 0.13)$ (Figure 3A). For standard metabolism, M. trossulus and hybrids had similar level > $1 \mathrm{ml} \mathrm{O}_{2} \mathrm{~h}^{-1} \mathrm{~g}^{-1}$, while M.edulis had a significantly lower value (30\%) (Figure3B). Furthermore, these lower levels of standard metabolism for M. edulis mussels were related to a 30\% higher shell growth rate (Figure 3C) and $25 \%$ higher dry mass tissue (Figure 3D) compared to similar lower values for M. trossulus and hybrids. These observations demonstrate significant relationships between MLH and basal metabolism for each species and hybrids, but none between MLH and growth rate, dry mass and condition index (Table 2).
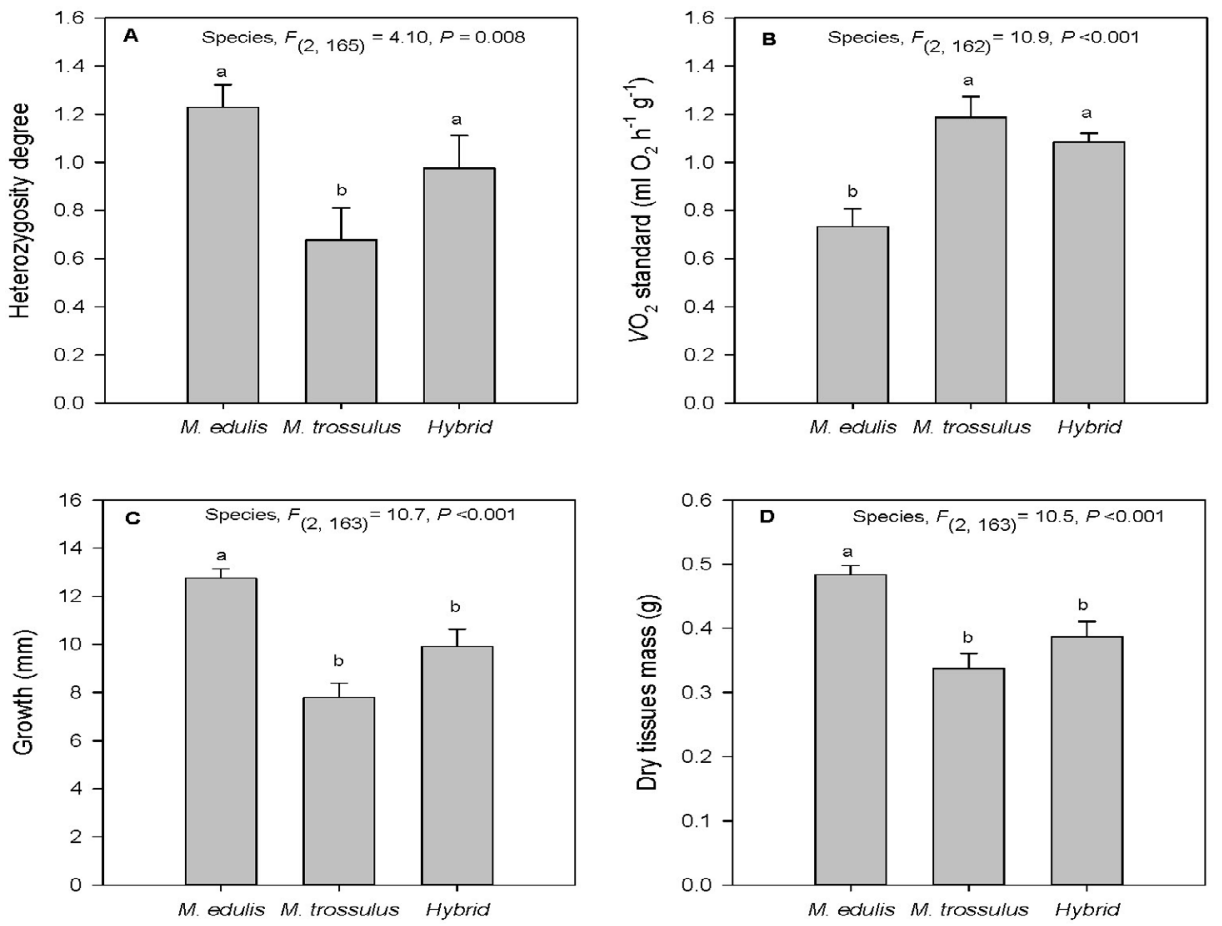

Figure 3: Multiple locus heterozygosity measured on allyzyme loci, standard metabolic rates, growth in shell length (mm) and dry tissues mass (g) for each species and hybrid after 8 weeks in condo cages in Country Harbour (Nova Scotia). $\mathrm{n}=64$

Table 2: Simple Pearson correlations relating standard metabolism $\left(\mathrm{ml} \mathrm{O}_{2} \cdot\right.$ ind $\left.^{-1} \bullet \mathrm{h}^{-1}\right)$, growth $(\mathrm{mm})$, dry tissue mass $(\mathrm{g})$ and condition index $(\mathrm{dry}$ meat mass/dry shell mass) with multiple locus heterozygosity (nb of heterozygous loci) for each species and hybrids. Bold are significant correlation.

\begin{tabular}{|c|c|c|c|c|}
\hline Species & MLHand basal metabolism & MLH and growth & MLH and dry tissue mass & Regression between MLH and condition index \\
\hline M. edulis & $\begin{array}{l}\mathrm{VO}_{2}=0.876-0.238 \mathrm{MLH} \\
\mathrm{r}^{2}=0.62, \mathrm{t}=-12.02, \boldsymbol{P}<\mathbf{0 . 0 0 0 1}\end{array}$ & $\begin{array}{l}\text { Growth }=13.12-0.295 \mathrm{MLH} \\
\mathrm{r}^{2}=0.005, \mathrm{t}=-0.69, P=0.45\end{array}$ & $\begin{array}{l}\text { Dry mass }=0.492-0.007 \text { MLH } \\
\mathrm{r}^{2}=0.002, \mathrm{t}=-0.44, P=0.66\end{array}$ & $\begin{array}{l}\text { Index }=0.149-0.001 \mathrm{MLH} \\
\mathrm{r}^{2}=0.001, \mathrm{t}=-0.19, P=0.85\end{array}$ \\
\hline M. trossulus & $\begin{array}{l}\mathrm{VO}_{2}=1.12-0.313 \mathrm{MLH} \\
\mathrm{r}^{2}=0.64, \mathrm{t}=-7.26, \boldsymbol{P}<\mathbf{0 . 0 0 0 1}\end{array}$ & $\begin{array}{l}\text { Growth }=7.82-0.031 \mathrm{MLH} \\
\mathrm{r}^{2}=0.001, \mathrm{t}=-0.18, P=0.86\end{array}$ & $\begin{array}{l}\text { Dry mass }=0.37-0.051 \mathrm{MLH} \\
\mathrm{r}^{2}=0.083, \mathrm{t}=-1.62, P=0.12\end{array}$ & $\begin{array}{l}\text { Index }=0.19-0.008 \mathrm{MLH} \\
\mathrm{r}^{2}=0.03, \mathrm{t}=-0.98, P=0.33\end{array}$ \\
\hline Hybrids & $\begin{array}{l}\mathrm{VO}_{2}=1.235-0.412 \mathrm{MLH} \\
\mathrm{r}^{2}=0.767, \mathrm{t}=-11.18, \boldsymbol{P}<\boldsymbol{0 . 0 0 0 1}\end{array}$ & $\begin{array}{l}\text { Growth }=10.09-0.186 \mathrm{MLH} \\
\mathrm{r}^{2}=0.001, \mathrm{t}=-0.22, P=0.83\end{array}$ & $\begin{array}{l}\text { Dry mass }=0.358-0.031 \mathrm{MLH} \\
\mathrm{r}^{2}=0.03, \mathrm{t}=1.10, P=0.28\end{array}$ & $\begin{array}{l}\text { Index }=0.155+0.007 \mathrm{MLH} \\
\mathrm{r}^{2}=0.03, \mathrm{t}=1.08, P=0.29\end{array}$ \\
\hline
\end{tabular}




\section{Discussion}

The results confirm our hypothesis that fitness-related mussel traits in aquaculture sites could be identified by readily available indicators, such as species composition, standard metabolism and MLH. Our results confirm previous studies showing that species composition of mussels in Atlantic Canada can affect the productivity of a stock within a site ${ }^{[8,12,14,15,17]}$. The growth experiment in this study is revealing that $M$. edulis in the bay studied was outperforming $M$. trossulus and hydrids both in terms of shell and tissue growth. This could be important not only for growth potential of mussels, but also for survival as there are a trade-offs between growth and reproduction ${ }^{[29,30]}$. At Loch Etive in Scotland, the presence of M. trossulus in M. edulis populations has been associated to over $50 \%$ losses in production due to poor meat contents and thin shells that were easily damaged during the harvesting and grading processes ${ }^{[31,32]}$. Thus, within mixed-species areas, M. edulis is likely outperforming $M$. trossulus and hybrids in terms of commercial quality. This could also lead to some ecological implication, given that the footprint of a mussel farm would vary with the resulting output in relation to the species composition. The combination of species is also presenting a major challenge in controlling the processing equipment to reduce shell breakage leading to higher mortalities, lower shelf life for thin shelled M. trossulus and hybrids or less clean shell for M. edulis.

We observed that higher performance of M. edulis comparatively to $M$. trossulus was linked to a lower level of standard metabolism (estimation of maintenance costs), related to a higher MLH. Maintenance costs represent the minimum energy to maintain animal alive and are related to an individual's size and volume ${ }^{[33]}$. As the size between species and hybrids were standardized to compare similar size classes, the differences observed could not be related to specific volume. Thus, our results suggest that $M$. edulis invest less energy to support maintenance requirements and could have more energy to resist to stress and to invest in growth and reproduction. This could also have ecological implications related to the different energy (food) requirement and biodeposition associated with species composition on a mussel farm. These results were in good agreement with studies indicating that more heterozygous mussels had a higher protein synthesis; higher lipids reserve accumulation and higher scope for growth ${ }^{[21,23,26]}$. The lower susceptibility of different $M$. edulis individual to stress was already related to lower standard metabolic rates and higher $\mathrm{MLH}^{[18,19,26]}$, but never used to explain differences between species and hybrids. This metabolic differences between species, could explained the results of Dias et al. ${ }^{[34]}$ showing that $M$. trossulus meat yields (expressed as the ratio of dry meat weight to total weight, a more suitable measure with lower shell weights of $M$. trossulus) varied considerably between different areas, but always lower than M. edulis. They also observed that hybrids were similar to $M$. trossulus rather than $M$. edulis. In our study, we noted that, for characteristics measured in relation to standard metabolism, shell and tissues growth for hybrids showed values similar to $M$. trossulus, but were significantly different from M. edulis. The only exception was with MLH, where similar values were observed between hybrids and M. edulis. In Newfoundland (Canada), studies on several sites revealed that growth rates in hybrids were intermediate between M. edulis and M. trossulus or statistically similar to one or other $\operatorname{species}^{[12]}$

Results on species composition in relation to mussels sizes, suggest differential survival potential between species. Within the same site, where M. edulis, M. trossulus and hybrids are found, the survival treats of $M$. edulis is likely higher, as their proportion doubled during the production cycle (between size classes of 5-15 to $25-50 \mathrm{~mm}$ ). This proportional increase corresponds to a decrease of $M$. trossulus species and supports the results from previous studies in Atlantic Canada ${ }^{[6,8,12,14,15,17,35]}$ and in Scotland ${ }^{[32]}$. We suggest that this survival traits in $M$. edulis, may be explained by the lower standard metabolism related compared to M. trossulus. As this metabolic rate is related to MLH, the use of MLH could be an indicator of mussel fitness ${ }^{[23,26,36,37]}$. Although the relationship between MLH and fitness could be controversial ${ }^{[38]}$, several studies showed that positive correlations are attributable to a more efficient use of energy in heterozygous individuals. Furthermore, this relation is particularly visible in animals exposed to stressful events ${ }^{[19,23,37,39,40]}$. Jenewein and Gosselin ${ }^{[41]}$ have demonstrated that tolerance to desiccation increase rapidly with the body size of juveniles $M$. trossulus. Thus, the decrease in the abundance of $M$. trossulus with body size observed in our study could be related to differential desiccation tolerance between species with $M$. edulis having higher resistance. This variation in survival rates within a production cycle have some ecological implications in relation to the footprint of a mussel farm. Higher mortality rates translate into larger farms, higher energy requirements for the same output from a mussel farm with mussels with higher survival rates, i.e. M. edulis. However, this hypothesis and related implications needs to be confirmed by other experiments. Another possibility to explain the decrease of $M$. trossulus abundance with body size is the differential predator-induced defenses observed between $M$. edulis and M. trossulus ${ }^{[13]}$. It has been clearly demonstrated that mussels in presence of predators, develop defense traits to resist the crushing claws of crabs or increase the effort required for sea stars to pry open the shell valves ${ }^{[42-45]}$. Lowen et al. ${ }^{[13]}$ have observed differential responses between species, with a thicker shell in presence of crabs and a greatly enlarged adductor muscle in presence of sea stars for M. edulis, but not in $M$. trossulus. These results suggest that M. trossulus is more susceptible than M. edulis to predation by sea stars and crabs and could explain, at least in part, the decrease in the proportion of $M$. trossulus in larger size classes. Finally, difference between physiological thermal tolerances of each species could also be considered to explain the decrease abundance of $M$. trossulus in relation to body size. Fly and Hilbish ${ }^{[46]}$ have demonstrated that $M$. edulis maintained a positive scope for growth (representing energy available for growth and/or reproduction above that necessary for maintenance requirements) in water temperature reaching $23^{\circ} \mathrm{C}$ comparatively $17^{\circ} \mathrm{C}$ for $M$. trossulus. As these bays are exposed to temperature over $17^{\circ} \mathrm{C}$ in summer months, selective mortality against $M$. trossulus could be related to longterm negative scope for growth.

It is not surprising to find the two mussels species in all sampled bays in Nova Scotia coast. Mytlilus spp. have a high dispersal potential, mostly due to their planktonic larval stage of several weeks combined to an important possibility of metamorphosis delay ${ }^{[47]}$ and drifting capacity through byssus production during their initial post-larval stage ${ }^{[48-50]}$. Coupled with large population size in this area ${ }^{[51]}$ and high fecundity ${ }^{[52,53]}$, mussel 
populations can maintain high levels of gene flow. The very low presence of M. trossulus and hybrids in St. Anne's could be explained by specific environmental conditions in this bay. Experimental works have demonstrated that $M$. trossulus larvae do not survive at high temperature comparatively to $M$. edulis ${ }^{[7,54]}$, and reflect the general distribution of these two species, with $M$. trossulus having a more northerly distribution compared to the more temperature distribution of $M$. edulis ${ }^{[55]}$. However, $M$. trossulus larvae showed higher resistance to low salinity than $M$. edulis ${ }^{[56]}$. This does not seem to persist after settlement, as the resistance to temperature and salinity were similar between the young juveniles of the two species. Salinity change the filtration activity of mussels, and $M$. trossulus showed clearly a higher acclimatization potential to salinity as low as $6.5 \mathrm{psu}^{[57]}$. This phenomenon along with pre-settlement mortality could explain, at least partially, the differential species composition observed between the bays for the younger size classes $(5-15 \mathrm{~mm})$. Wave exposure could be also involved in the differential distribution between the bays, although both species coexist in sheltered and exposed habitats. Finally, M. edulis seems to be the only species able to survive in highly sheltered habitats, but this may be link to temperature rather than wave exposure (Tam and Scrosati, 2014).

\section{Conclusion}

Our results suggest that mussels collected in areas where species co-exist seem less optimal for seed collection and that the culture activities in these sites should rely on seed transfer from M. edulis. Furthermore, the use of the two species and their hybrids can increase both the economic and ecological cost of farming mussels and may affect the sustainability of these operations in some areas. Finally, our results confirm that standard metabolism and MLH estimated on enzymes involved in metabolic activities are two good indicators of performance for M. edulis and M. trossulus in terms of growth (shell and tissues).

\section{Acknowledgements}

We would like to thanks Lorraine Hamilton from the Aquatic Biotechnology Laboratory from Fisheries and Oceans Canada for their works on molecular markers. This project was supported by the Aquaculture Collaborative Research and Development Program (ACRDP) of Fisheries and Oceans, Canada, to T. Landry and the Natural Sciences and Engineering Research Council of Canada (NSERC-Discovery Grant to R. Tremblay 299100).

\section{References}

1. The State of World Fisheries and Aquaculture: Opportunities and challenges. (2014) Food and Agriculture organization of the United Nations 223p

2. Statistics Canada, 2010. Canadian agriculture statistics - aquaculture statistiques 2009. Report no. 23-222-X, 40 pp.

3. LeBlanc, N., Landry, T., Stryhn, H., et al. The effect of high air and water temperature on juvenile Mytilus edulis in Prince Edward Island, Canada. (2005) Aquaculture 243: 185-194.

4. Koehn, R.K., Hall, J.G., Innes, D.J., et al. Genetic differentiation of Mytilus edulis in eastern North America. (1984) Mar Biol 79(2): 117126.

5. McDonald, J.H., Seed, R., Kohen, R.K., et al. Allozymes and mor- phometric characters of three species of Mytilus in the Northern and Southern hemispheres. (1991) Mar Biol 111(3): 323-333.

6. Comesaña, A.S., Toro, J. E., Innes, D. J., et al. A molecular approach to the ecology of a mussel (Mytilus edulis - M.trossulus) hybrid zone on the east coast of Newfoundland, Canada. (1999) Mar Biol 133(2): 213-221.

7. Hayhurst, S., Rawson, P.D. Species-specific variation in larval survival and patterns of distribution for the blue mussels Mytilus edulis and Mytilus trossulus in the Gulf of Maine. (2009) J Mollus Stu 75(3): 215-222.

8. Toro, J., Innes, D.J., Thompson, R.J. Genetic variation among life-history stages of mussels in a Mytilus edulis-M. trossulus hybrid zone. (2004) Mar Biol 145(4): 713-725.

9. Moreau, V., Tremblay, R., Bourget, E. Distribution of Mytilus edulis and M. trossulus on the Gaspe coast in relation to spatial scale. (2005) J Shellfish Res 24(2): 545-551.

10. Tam, J.C., Scrosati, R.A. Distribution of cryptic mussel species (Mytilus edulis and M. trossulus) along wave exposure gradients on northwest Atlantic rocky shores. (2014) Mar Biol Res 10(1): 51-60.

11. Sabirov, M.A. Modeling of the temporal and local spatial structure variability in mixed settlements of Mytilus edulis and Mytilus trossulus. (2014) J Evol Biochem Physiol 50(1): 91-93.

12. Penney, R.W., Hart, M.J., Templeman, N. Comparative growth of cultured blue mussels, Mytilus edulis, M. trossulus and their hybrids, in naturally occurring mixed-species stocks. (2002) Aquacult Res 33(9): 693-702.

13. Lowen, J.B., Innes, D.J., Thompson, R.J. Predator-induced defenses differ between sympatric Mytilusedulis and M. trossulus. (2013) Mar Ecol Prog Ser 475: 135-143.

14. Penney, R.W., Hart, M.J., Templeman, N.D. Genotype-dependent variability in somatic tissue and shell weights and its effect on meat yield in mixed species [Mytilus edulis L., M. trossulus (Gould), and their hybrids] cultured mussel populations. (2008) J Shellfish Res 27(4): 827-834.

15. Penney, R.W., Hart, M.J., Templeman, N.D. Genotype-dependent survival, growth, and production in cultured blue mussels, Mytilus spp.: Results of a reciprocal seed transfer experiment. (2006) J Shellfish Res 25(2): 515-525.

16. Penney, R.W., Hart, M.J., Templeman, N.D. Shell strength and appearance in cultured blue mussels Mytilus edulis, M-trossulus, and M-edulis x M-trossulus hybrids. (2007) N Am J Aquacult 69(3): 281295.

17. Mallet, A.L., Carver, C.E.A. Comparative growth and survival patterns of Mytilus trossulus and Mytilus edulis in Atlantic Canada. (1995) Can J Fish Aquat Sci 52(9): 1873-1880.

18. LeBlanc, N., Tremblay, R., Davidson, J., et al. The effect of selection treatments on Mytilus edulis, modifications of genetic and physiological characteristics. (2008) Mar Biol 153(6): 1142-1152.

19. Myrand, B., Tremblay, R., Sévigny, J.M. Selection against blue mussels (Mytilus edulis L.) homozygotes under various stressful conditions. (2002) J Hered 93(4): 238-248.

20. Hofmann, G., Somero, G. Evidence for protein damage at environmental temperatures: seasonal changes in levels of ubiquitin conjugates and hsp70 in the intertidal mussel Mytilus trossulus. (1995) J Exp Biol 198(Pt 7): 1509-1518.

21. Hawkins, A.J.S., Widdows, J., Bayne, B.L. The relevance of wholebody protein metabolism to measure costs of maintenance and growth in Mytilus edulis. (1989) Physiol Zool 62(3): 745-763.

22. Myrand, B., Tremblay, R., Sévigny, J.M. Decreases in multi-locus heterozygosity in suspension-cultured mussels (Mytilus edulis) through loss of the more heterozygous individuals. (2009) Aquaculture 295(34): $188-194$.

23. Tremblay, R., Landry, T., Leblanc, N., et al. Physiological and biochemical indicators of mussel seed quality in relation to temperatures. (2011) Aquat Living Resour. 24: 273-282.

24. Myrand, B., Gaudreault, J. Summer mortality of blue mussels (Mytilus edulislinneaus, 1758) in the Magdalen Islands (southern gulf 
of the St-Lawrence, Canada). (1996) Oceanographic Literature Review 43(9): 934.

25. Bayne, B. L. Aspects of the metabolism of Mytilus edulis during starvation. (1973) Neth J Sea Res 7: 399-410.

26. Tremblay, R., Myrand, B., Sévigny, J.M., et al. Bioenergetic and genetic parameters in relation to susceptibility of blue mussels, Mytilus edulis (L.) to summer mortality. (1998) J Exp Mar Biol Ecol 221(1): 27-58.

27. Tremblay, R., Myrand, B., Sevigny, J.M. Genetic characterization of wild and suspension-cultured blue mussels (Mytilus edulis Linneaus, 1758 ) in the Magdalen Islands (southern Gulf of St. Lawrence, Canada). (1998a) J Shellfish Res 17: 1191-1202.

28. Rice, W. R. Analyzing tables of statistical tests. (1989) Evolution 43(1): 223-225

29. Chauvaud, L., Patry, Y., Jolivet, A., et al. Variation in size and growth of the Great Scallop Pecten maximus along a latitudinal gradient. (2012) Plos One 7(5): 37717.

30. Irie, T., Iwasa, Y. Optimal growth pattern of defensive organs: the diversity of shell growth among mollusks. (2005) Am Nat 165(2): 238249.

31. Beaumont, A.R., Hawkins, M.P., Doig, F.L., et al. Three species of Mytilus and their hybrids identified in a Scottish Loch: natives, relicts and invaders? (2008) J Exp Mar Biol Ecol 367(2): 100-110.

32. Dias, P.J., Piertney, S.B., Snow, M., et al. Survey and management of mussel Mytilus species in Scotland. (2011a ) Hydrobiologia 670:127140.

33. Kooijman, S.A., Dynamic energy and mass budgets in biological systems. (2000) Cambridge, University Press.

34. Dias, P.J., Malgrange, B., et al. Performance of mussels, Mytilus edulis, Mytilus trossulus and their hybrids in cultivation at three Scottish Lochs. (2011) J World Aquacult Soc 42(1): 111-121.

35. Penney, R.W., Hart, M.J. Distribution, genetic structure, and morphometry of Mytilus edulis and M. trossulus within a mixed species zone. (1999) J Shelfish Res 18(2): 367-374.

36. Brokordt, K., Leiva, N., Jeno, K., et al. Effect of allozyme heterozygosity on basal and induced levels of heat shock protein (Hsp70), in juvenile Concholepasconcholepas (Mollusca). 2009 J Exp Mar Biol Ecol 370(1-2): 18-26.

37. Gentili, M.R., Beaumont, A.R. Environmental stress, heterozygosity, and growth rate in Mytilus edulis L. (1988) J Exp Mar Biol Ecol 120(2): 145-153.

38. Britten, H.B. Meta-analyses of the association between multilocus heterozygosity and fitness. (1996) Evolution 50(6): 2158-2164.

39. Beaumont, A.R., Toro, J. Allozyme genetics of Mytilus edulis subjected to copper and nutritive stress. (1996) J Mar Biol Ass 76(04): 1061-1071.

40. Lesbarreres, D., Primmer, C., Laurila, A., et al. Environmental and population dependency of genetic variability-fitness correlations in Rana temporaria. (2005) Mol Ecol 14(1): 311-323.

41. Jenewein, B.T., Gosselin, L.A. Ontogenetic shift in stress tolerance thresholds of Mytilus trossulus: effects of desiccation and heat on juvenile mortality. (2013) Mar Ecol Prog Ser 481: 147-159.
42. Freeman, A.S., Specificity of induced defenses in Mytilus edulis and asymmetrical predator deterrence. (2007) Mar Ecol Prog Ser 334: 145-153.

43. Freeman, A.S., Meszaros, J., Byers, J.E. Poor phenotypic integration of blue mussel inducible defenses in environments with multiple predators. (2009) Oikos 118(5): 758-766.

44. Leonard, G., Bertness, M.D., Yund, P. Crab predation, waterborne cues, and inducible defenses in the blue mussel, M. edulis. (1999) Ecology 80(1): 1-14.

45. Reimer, O., Harms-Ringdahl, S. Predator-inducible changes in blue mussels from the predator-free Baltic Sea. (2001) Mar Biol 139: 959965.

46. Fly, E.K., Hilbish, T.J. Physiological energetics and biogeographic range limits of three congeneric mussel species. (2013) Oecologia 172(1): 35-46.

47. Martel, A.L., Tremblay, R., Myrand, B., et al. Veliger size at metamorphosis and temporal variability in prodissoconch II morphometry in the blue mussel (Mytilus edulis): Potential impact on recruitment. (2014) J Shellfish Res 33(2): 443-455.

48. Lane, D.J., Beaumont, A.R., Hunter, J.R. Byssus drifting and the drifting threads of the young post-larval mussel Mytilus edulis. (1985) Mar Biol 84(3): 301-308.

49. Siegel, D.A., Kinlan, B.P., Gaylord, B., et al.. Lagrangian descriptions of marine larval dispersion. (2003) Mar Ecol Prog Ser 260: 83-96. 50. Toupoint, N., Solomon-Gilmore, L., Bourque, F., et al. Match/mismatch between the Mytilus edulis larval supply and seston quality: effect on recruitment. (2012) Ecology 93: 1922-1934.

51. Hunt, H.L., Scheibling, R.E. Spatial and temporal variability patterns of colonization by mussels (Mytilus trossulus, M. edulis) on a wave-exposed rocky shore. (1998) Mar Ecol Prog Ser 167:155-169.

52. Kautsky, N. Quantitative studies on gonad cycle, fecundity, reproductive output and recruitment in a Baltic Mytilus edulis population. (1982) Mar Biol 68: 143-160.

53. Myrand, B., Guderley, H., Himmelman, J.H. Reproduction and summer mortality of blue mussels Mytilus edulis in the Magdalen Islands, southern Gulf of St. Lawrence (2000) Mar Ecol Prog Ser 197: 193-207.

54. Rayssac, N., Pernet, F., Lacasse, O., et al., Temperature effect on survival, growth, and triacylglycerol content during the early ontogeny of Mytilus edulis and M. trossulus. (2010) Mar Ecol Prog Ser 417: 183191.

55. Gosling, E.M. In The mussel Mytilus: ecology, physiology and genetics. Developments in aquaculture and fisheries science. (1992) Elsevier, Amsterdam 7: 309-380.

56. Qiu, J.W., Tremblay, R., Bourget, E. Ontogenetic changes in hyposaline tolerance in the mussels Mytilusedulis and M. trossulus: implications for distribution. (2002) Ecol Prog Ser 228: 143-152.

57. Riisgard, H.U., Mulot, M., Merino, L., et al. Effect of salinity-changing rates on filtration activity of mussels from two sites within the Baltic Mytilus hybrid zone: The brackish Great Belt (Denmark) and the low saline central Baltic Sea. (2014) Open J Mar Sci 4(2): 101-109.
Ommega Online Publishers

Journal Title: Journal of Marine Biology and Aquaculture Journal Short Name: J Marine Biol Aquacult
Journal ISSN 2381-0750

E-mail: marinelife@ommegaonline.org

Website:_www.ommegaonline.org 